\title{
REDETERMINATION OF SECONDARY STANDARDS OF WAVE LENGTH FROM THE NEW INTERNATIONAL IRON ARC.
}

\author{
By W. F. Meggers, C. C. Kiess, and Keivin Burns.
}

ABSTRACT.

The system of secondary standards of wave length now in common use was derived from an axial part about $2 \mathrm{~mm}$ wide in the center of an iron arc about $6 \mathrm{~mm}$ long, and was established before the full importance of operating conditions of sources was recognized. In this type of arc certain lines, grouped as $c$ and $d$ lines because of their sensitiveness to pressure, appeared to be displaced with respect to others grouped as $a$ and $b$ lines, so that the International Astronomical Union in 1922 recommended that the length of the arc be 12 to $\mathrm{x} 5 \mathrm{~mm}$ and that light be taken from a central zone not to exceed $\mathrm{I}-\mathrm{I} .5 \mathrm{~mm}$ in width. These changes in the standard iron arc made it desirable to redetermine the secondary standards of wave length. The well-known interferometer method of Fabry and Perot was employed to measure wave lengths of selected lines in the iron spectrum directly in terms of the primary standard, the wave length of the red radiation from cadmium which served for the wave-length meter comparisons. New results are given for $\mathrm{r}_{59}$ lines between $3370 \mathrm{~A}$ and $6678 \mathrm{~A}$, including 84 of the international secondary standards. For 23 lines belonging to groups $\mathrm{c}$ and $\mathrm{d}$, the secondary standards minus the new values averages $+0.0072 \mathrm{~A}$. There is also a systematic difference for lines of groups a and b, 44 such lines averaging $0.0029 \mathrm{~A}$ less than the present international values. The reason for the latter divergence is not obvious, but it may be due to a real error in the international system, which, it is pointed out, was not established strictly according to the logical definitions of such a system nor with the accuracy which might be possible now in a redetermination.

\section{CONTENTS.}

I. Introduction $\ldots \ldots \ldots \ldots \ldots \ldots \ldots \ldots \ldots \ldots \ldots \ldots \ldots \ldots \ldots \ldots \ldots,{ }_{26} 6_{3}$

II. Apparatus and methods. $\ldots \ldots \ldots \ldots \ldots \ldots \ldots \ldots \ldots \ldots \ldots \ldots \ldots \ldots \ldots \ldots \ldots \ldots \ldots, 264$

III. Results. ..................................... ${ }^{26} 6_{7}$

IV. Discussion.................................... 270

\section{INTRODUCTION.}

An international system of secondary standards of wave length, derived from the iron arc spectrum, was established by the International Union for Cooperation in. Solar Research during the years I 905 to I 913 . This system comprises 86 values ${ }^{1}$ extending from $3370.789 \mathrm{~A}$ in the ultra-violet to $6750.163 \mathrm{~A}$ in the red, and for more than a decade it has been used very extensively in spectroscopy and astrophysics. The values are based upon three independent observations by the interferometer method of Fabry and Perot, and are referred to the value $6438.4696 \mathrm{~A}$, obtained by

J. O. S. A., 5, p. 308; 1921. 
Benoit, Fabry, and Perot, for the red radiation of cadmium in terms of the meter. The actual comparisons of wave length were made before the full importance of operating conditions of sources was realized and it was not until 1913 that the iron arc in air as a source of international standards ${ }^{2}$ was carefully specified as follows: Length of arc $6 \mathrm{~mm}$; current of 6 amperes for wave length greater than $4000 \mathrm{~A}, 4$ amperes or less for wave lengths shorter than $4000 \mathrm{~A}$; direct current with positive pole above the negative, potential of 220 volts; iron rods of $7 \mathrm{~mm}$ diameter for electrodes; axial part about $2 \mathrm{~mm}$ wide in center of arc to be used as the source of light; only lines of groups a, b, c, d to be used as standards. Somewhat later, it was shown by investigations ${ }^{3}$ at the $\mathrm{Mt}$. Wilson Observatory that the lines of groups $c$ and $d$ were displaced toward the red in this type of arc. This displacement, affecting about 20 of the secondary standards, was regarded as a change in wave length of these lines as compared with lines of groups a and $b$, which were assumed to be independent of ordinary variations in the source. .

In July, I9I9, the International Astronomical Union was organized to replace the union which existed before the war and its transactions for 1922 contained the following statement with respect to the iron arc: ${ }^{4}$

In order to obtain lines of constant wave length, constant intensity distribution and adapted to high orders of interference, the adoption is recommended of the Pfund arc operated between IIO and 250 volts, with 5 amperes or less, at a length of $12-15$ mm used over a central zone not to exceed I-1.5 mm in width, and with an iron rod $6-7 \mathrm{~mm}$ diameter as the upper pole and a bead of oxide of iron as the lower pole.

In view of these radical changes in the standard iron arc, it became desirable to redetermine the secondary standards of wave length, and in this paper new results are given for I59 lines, including 84 of the international secondary standards.

\section{APPARATUS AND METHODS.}

A newly constructed iron arc was used in this investigation. The arc stand without electrodes is shown in Figure I. In order to select the proper length and portion of the arc, it is convenient to have adjustments in three dimensions as well as additional ones for aligning and separating the electrodes. Iron rods 7 $\mathrm{mm}$ in diameter were used as electrodes and the upper or positive pole was surrounded by a close fitting brass cylinder perforated with holes to serve as a radiator.

2 Trans. I. U.S. R., 4, p. 58; I9I4.

${ }^{3}$ Astroph. J., 42, p. 231; 1915; Ibid., 46, p. I38; 1917.

- Trans. I. A. U., 1, p. 36; 1922. 
Scientific Papers of the Bureau of Standards, Vol. 19

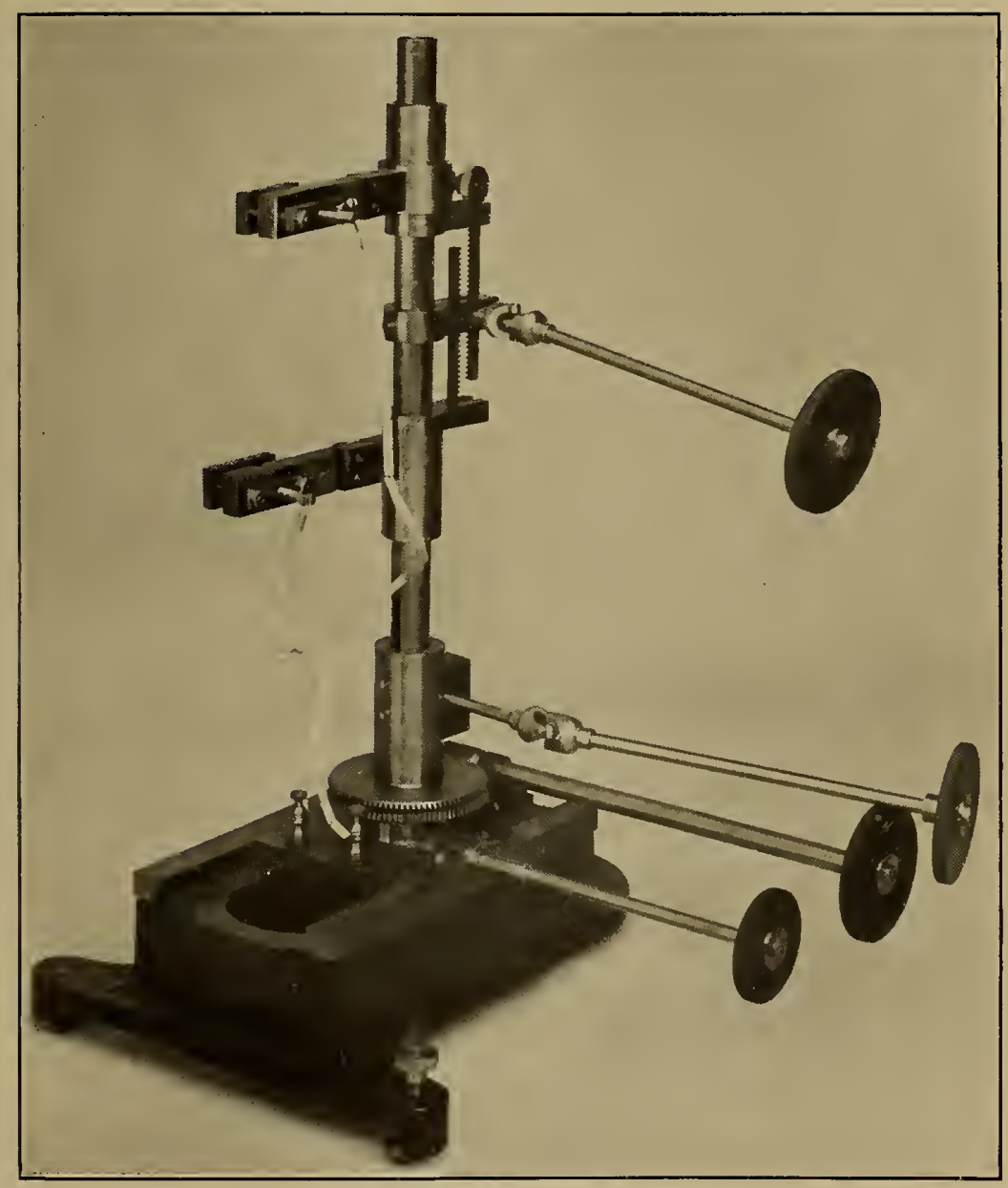

FIG. I. - New stand for the iron arc. 
The cadmium source was a spectrum tube of the $H$ type similar to the one described by Michelson. This type of tube served as a source in both of the meter measurements in terms of the wave length of the red radiation from cadmium vapor, and is the one mentioned in the definition of the unit of wave length. ${ }^{5}$ The International Astronomical Union has defined some auxiliary standards ${ }^{6}$ in the neon spectrum as equivalent in most cases to the primary standard, and we have accordingly used neon tubes for part of the comparison exposures. Tubes similar to the one used for neon and cadmium wave-length comparisons ${ }^{7}$ were employed and served in every case to determine the order of interference in the convenient manner described heretofore.?

A quartz lens projected a fourfold magnified image of the arc on the interferometer which was diaphragmed to a $6 \mathrm{~mm}$ aperture, the latter thus receiving light from about $1.5 \mathrm{~mm}$ in the center of a $12 \mathrm{~mm}$ arc.

Nearly half of the exposures were made simultaneously to the iron arc and the comparison sources, cadmium or neon, and in such cases the light from the arc was reflected to the interferometer by a thinly silvered mirror, through which the light from the comparison sources passed. When exposures were not made simultaneously the comparison source was photographed both before and after the iron arc, and the iron wave lengths were then derived from the mean of the two comparison exposures. An arrangement whereby exposures could be made simultaneously to three different sources, viz, iron, cadmium, and neon, was also tried, but finally discarded because of its wastefulness of light.

Two sets of interferometer plates were employed, the one set being cathodically covered with semitransparent films of silver and the other with nickel. Various separations of the interferometer plates were used in different exposures, the separators or étalons being of invar and having lengths ranging from 3 to I $5 \mathrm{~mm}$. The interferometer plates were mounted in the cylindrical holder described elsewhere ${ }^{8}$ and the whole interferometer was slipped into a long brass tube packed in granulated cork, and thus protected from any air currents and outside temperature changes which might occur.

For dispersing the spectra the stigmatic concave grating mounting described before ${ }^{9}$ was employed. The observations were made

5 Trans. I. U. S. R., 2, p. 20; 1908.

6 Trans. I. A. U., 1, p. 35; 1922.

7 B. S. Sci. Papers, 12, p. 203; 1915.

${ }^{8}$ B. S. Bull., 14, p. 711 ; 1918 .

B. S. Sci. Papers, 18, p. rgr; 1922. 
in a basement laboratory whose diurnal temperature fluctuations are negligible, and both the arc and the cadmium lamp furnace were inclosed in ventilated hoods so that there was no difficulty with temperature effects on the apparatus.

Schleussner "ultra-rapid" plates, $40 \mathrm{~cm}$ long by $6 \mathrm{~cm}$ wide, were employed in photographing the spectra. These plates were of extra thin glass, which permitted them to be bent to the best focus for spectral lines and interference rings throughout the entire spectrum extending from about $3000 \mathrm{~A}$ in the ultra-violet to about $7000 \mathrm{~A}$ in the red. The end of the plate used for recording the yellow, orange, and red was sensitized by bathing in a pinacyanol solution. The light from the iron arc was passed through a Wratten minus blue filter for part of the long exposures in order that the green, yellow, and red portions of the spectrum might be more comparable with the ultra-violet in photographic density. Some extra short exposures were made in order to obtain good images of the stronger lines which were otherwise generally overexposed, especially in the ultra-violet. A summary of the plates and data relating to them is contained in Table $\mathbf{I}$.

TABLE 1.-Summary of Observations.

\begin{tabular}{|c|c|c|c|}
\hline Plate No. & Étalon. & Film. & Exposures of sources (in minutes). \\
\hline $\begin{array}{l}\text { G } 1381 \ldots \ldots \ldots \\
\text { G } 1383 \ldots \ldots \ldots \\
\text { G } 1384 \ldots \ldots \\
\text { G } 1385 \ldots \ldots \ldots \\
\text { G } 1398 \ldots \ldots \ldots \\
\end{array}$ & $\begin{array}{c}\mathrm{mm} \\
3 \\
5 \\
7.5 \\
10 \\
3\end{array}$ & $\begin{array}{l}\mathrm{Ni} \\
\mathrm{Ni} \\
\mathrm{Ni} \\
\mathrm{Ni} \\
\mathrm{Ag}\end{array}$ & $\begin{array}{l}\mathrm{Ne}, 25 ; \mathrm{Fe}, 40 ; \mathrm{Ne}, 20 . \\
\mathrm{Cd}, 25 ; \mathrm{Fe}, 45 ; \mathrm{Ne}, 12 . \\
\mathrm{Cd}, 20 ; \mathrm{Fe}, 60 ; \mathrm{Ne}, 12 . \\
\mathrm{Cd}, 30 ; \mathrm{Fe}, 60 ; \mathrm{Ne}, 12 . \\
\mathrm{Cd}, 50 ; \mathrm{Fe}, 60 ; \mathrm{Fe}, 5 ; \mathrm{Ne}, 15 .\end{array}$ \\
\hline $\begin{array}{l}\text { G } 1399 \ldots \ldots \\
\text { G } 1400 \ldots \ldots \\
\text { G } 1401 \ldots \ldots \\
\text { G } 1402 \ldots \ldots \\
\text { G } 1403 \ldots \ldots\end{array}$ & \begin{tabular}{c|}
5 \\
7.5 \\
7.5 \\
10 \\
15
\end{tabular} & $\begin{array}{l}\mathrm{Ag} \\
\mathrm{Ag} \\
\mathrm{Ag} \\
\mathrm{Ag} \\
\mathrm{Ag}\end{array}$ & $\begin{array}{l}\mathrm{Cd}, 35 ; \mathrm{Fe}, 60 ; \mathrm{Fe}, 3 ; \mathrm{Ne}, 10 . \\
\mathrm{Cd}, 30 ; \mathrm{Fe}, 70 ; \mathrm{Fe}, 3 ; \mathrm{Ne}, 10 . \\
\mathrm{Cd}, 20 ; \mathrm{Fe}, 90 ; \mathrm{Fe}, 5 \mathrm{Ne}, 12 . \\
\mathrm{Cd} 20 ; \mathrm{Fe} 90 ; \mathrm{Fe}, 5 ; \mathrm{Ne}, 10 . \\
\mathrm{Cd}, 25 ; \mathrm{Fe}, 90 ; \mathrm{Fe}, 1.5 ; \mathrm{Ne}, 12 .\end{array}$ \\
\hline 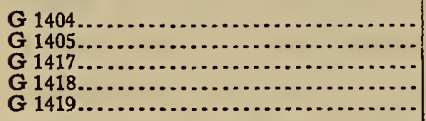 & $\begin{array}{r}5 \\
3 \\
10 \\
10 \\
10\end{array}$ & $\begin{array}{l}\mathrm{Ag} \\
\mathrm{Ag} \\
\mathrm{Ag} \\
\mathrm{Ag} \\
\mathrm{Ag}\end{array}$ & $\begin{array}{l}\mathrm{Ne}, 10 ; \mathrm{Fe}, 80 ; \mathrm{Fe}, 1.5 ; \mathrm{Ne}, 10 . \\
\mathrm{Ne} 15 ; \mathrm{Fe}, 70 ; \mathrm{Fe}, 1.5 ; \mathrm{Ne}, 20 \text {. } \\
\mathrm{Fe} \text { Ne, simultaneously, } 40 . \\
\text { Fe, Ne, simultaneously, } 60 . \\
\text { Fe, Ne, slmultaneously, } 5,60 .\end{array}$ \\
\hline $\begin{array}{l}\text { G } 1420 \ldots \ldots \ldots \ldots \\
\text { G } 1439 \ldots \ldots \ldots \ldots \\
\text { G } 1440 \ldots \ldots \ldots \ldots \\
\text { G } 1441 \ldots \ldots \ldots \ldots \\
\text { G } 1442 \ldots \ldots \ldots \ldots\end{array}$ & $\begin{array}{l}7.5 \\
7.5 \\
7.5 \\
7.5 \\
7.5\end{array}$ & $\begin{array}{l}\mathrm{Ag} \\
\mathrm{Ag} \\
\mathrm{Ag} \\
\mathrm{Ag} \\
\mathrm{Ag}\end{array}$ & $\begin{array}{l}\text { Fe, Ne, simultaneously, } 1,60 . \\
\text { Fe, Ne, simultaneously, } 65 . \\
\text { Fe, Ne, simultaneously, } 60 . \\
\text { Fe, Cd, simultaneously, } 60 . \\
\text { Fe, Ne, simultaneously, } 75 \text {. }\end{array}$ \\
\hline $\begin{array}{l}\text { G } 1444 \ldots \ldots \\
\text { G } 1446 \ldots \ldots\end{array}$ & $\begin{array}{l}5 \\
3\end{array}$ & $\begin{array}{l}\mathrm{Ag} \\
\mathrm{Ag}\end{array}$ & $\begin{array}{l}\text { Fe, Cd, simultaneously, } 75 \text {. } \\
\text { Fe, Cd, simultaneously, } 60 \text {. }\end{array}$ \\
\hline
\end{tabular}

Thege neral theory of the classical étalon interferometer method of Fabry and Perot ${ }^{10}$ for wave-length comparisons is so well known, both as to the arrangement of apparatus and reduction of the results, that it does not require repetition here. Details 
about the particular apparatus and procedure involved in the present investigation have already been given above and the following remarks on measurements, computations, and corrections should suffice. In general, the diameters of two interference rings were measured for each standard line, the innermost ring either being avoided if its fractional order was less than 0.4 or being supplemented by observations on the third ring. Several of the plates were reduced from measurements of three rings for each line. The computations were made by means of the formula

$$
\lambda_{1}=\frac{\lambda P}{P_{1}}\left(\mathrm{I}+\frac{d^{2}}{8 R^{2}}-\frac{d_{1}^{2}}{8 R^{2}}\right)
$$

in which $\lambda_{1}$ represents the wave length of a secondary standard to be ascertained in terms of $\lambda$, the wave length of the primary standard, $P_{1}$ and $P$ are, respectively, the orders of interference producing the first ring in each case, $d_{1}$ and $d$ represent the linear diameters of these two rings, respectively, and $R$ is the focal length of the lens which focuses the interference rings on the slit of the spectrograph. Small corrections required by deviation of the observing conditions from the standard temperature and atmospheric pressure were made according to the Bureau of Standards tables, ${ }^{11}$ which have been adopted for this purpose by the International Astronomical Union. The corrections for the so-called dispersion of phase change were determined from étalons of various sizes ${ }^{12}$ and were confirmed by a supplementary set of observations on neon and mercury lines for which étalons up to $25 \mathrm{~mm}$ in length were used.

\section{RESULTS.}

The original recommendation in establishing an international system of standard wave lengths was that secondary standards be determined by an interference method at intervals of 50 Angstroms, and that tertiary standards be derived from these by interpolation. Since the labor involved in measuring wave lengths directly in terms of the primary standard is not much greater than that required for the same precision by interpolation, we have in the present work measured lines at closer intervals. In Table 2 we present results for 159 lines, including 84 of the international secondary standards, in the spectral range 3370 to $6678 \mathrm{~A}$, thus 
giving standards at intervals which average about $20 \mathrm{~A}$. Column I in Table I describes each line as to intensity, group, and class, the relative intensities being the estimates of Burns, ${ }^{13}$ while the data on group and class, as far as these are available, are taken from Gale and Adams, ${ }^{14}$ and additional group classifications by St. John and Babcock. ${ }^{1}$

The wave lengths resulting from direct comparison with the primary standard are found in column 2, followed by the number of observations and the probable error for each value. " $\mathrm{A}$ " indicates a probable error less than $0.0007 \mathrm{~A}$, "B" corresponds to a probable error between $0.0007 \mathrm{~A}$ and $0.0012 \mathrm{~A}$, while "C" means that the determination is poor. For comparison with column 2, column 5 contains the fractional values of the international secondary standards and column 6 the interpolated values and tertiary standards adopted by the International Astronomical Union. ${ }^{10}$

With respect to the choice of standards, the International Astronomical Union has expressed itself as follows: ${ }^{17}$

It is very desirable to eliminate as far as possible the unstable standards belonging to groups $c 5$ and $d$. The list of proposed tertiaries shows that stable Fe lines are available as soon as their wave lengths are referred directly to the red cadmium line, except for the short gap between 4700 and $4800 \mathrm{~A}$ and for the region 5500-6000 A. This long gap can be partially filled by neon lines, whose wave lengths have been referred to the red cadmium line by three observers, and this entire gap as well as that at $475^{\circ} \mathrm{A}$ can be filled with good solar lines, when their wave lengths in integrated sunlight have been determined by a sufficient number of interferometer observations.

It should be emphasized, however, that no solar spectrum standards on the new international scale are, as yet, available, and that not all laboratories have access to the solar spectrum. Furthermore, it is conceivable that in some cases the use of a neon tube requiring different electrical facilities than the iron arc, may be inconvenient. Since the neon lines fill only one-third of one of the gaps mentioned above, it is perhaps doubtful if the neon tube will be very generally employed to supplement the iron arc. For these reasons we believe that it is highly desirable to make the iron arc serve, as far as possible, as a source of standards for the entire range of wave lengths, and we have, therefore, in our measurements, included $\mathrm{I} 7$ lines of group c, 22 of group d, and 3 of group e to fill the spectral regions, either because no other iron lines are available there or to distribute the standards more evenly. Ac-

${ }^{13}$ Lick Observatory Bulletin No. 247, also Zeit. f. Wiss. Phot., 12, p. 209 ; xgra."

${ }_{14}$ Astroph. Jour., 35, p. xo; x912; also, Astroph. Jour., 37, p. 39r; I913.

${ }^{15}$ Astroph. Jour., 53, p. 260; x92x.

${ }_{16}$ Trans. I. A. U., 1, p. 4I; 1922.

${ }^{17}$ Ibid., p. 38. 
${ }_{\text {Burns }}^{\text {Meggers, Kiess, }}$ ] Secondary Standards of Wave Lengths.

cording to our experience any and all of these values are strictly reproducible under the same observing conditions and may be used with confidence in precision measurements of lengths.

TABLE 2.-Standard Wave Lengths in the Iron Arc Spectrum.

\begin{tabular}{|c|c|c|c|c|c|c|c|c|c|c|c|}
\hline $\begin{array}{l}\text { Intensity, } \\
\text { group and } \\
\text { class. }\end{array}$ & $\lambda$ B. S. & $\begin{array}{l}\text { Num- } \\
\text { ber of } \\
\text { obser- } \\
\text { va- } \\
\text { tions. }\end{array}$ & $\begin{array}{c}\text { Prob- } \\
\text { able } \\
\text { error. }\end{array}$ & $\begin{array}{l}\text { Sec- } \\
\text { ond- } \\
\text { ary } \\
\text { stand- } \\
\text { ards. }\end{array}$ & $\begin{array}{c}\text { Inter- } \\
\text { po- } \\
\text { lated. }\end{array}$ & $\begin{array}{l}\text { Intensity, } \\
\text { group } \\
\text { and } \\
\text { class. }\end{array}$ & $\lambda$ B. S. & $\begin{array}{l}\text { Num- } \\
\text { ber of } \\
\text { obser- } \\
\text { va- } \\
\text { tions. }\end{array}$ & $\begin{array}{l}\text { Prob- } \\
\text { able } \\
\text { error. }\end{array}$ & $\begin{array}{l}\text { Sec- } \\
\text { ond- } \\
\text { ary } \\
\text { stand- } \\
\text { ards. }\end{array}$ & $\begin{array}{l}\text { Inter- } \\
\text { po- } \\
\text { lated. }\end{array}$ \\
\hline & $\begin{array}{l}3370.786 \\
3399.337 \\
3428.196 \\
3445.151 \\
3485.343\end{array}$ & $\begin{array}{r}9 \\
13 \\
11 \\
18 \\
11\end{array}$ & $\begin{array}{l}\mathbf{A} \\
\mathbf{A} \\
\mathbf{A} \\
\mathbf{A} \\
\mathbf{A}\end{array}$ & \begin{tabular}{c}
789 \\
337 \\
\hdashline 154 \\
345
\end{tabular} & $\begin{array}{r}788 \\
337 \\
-153 \\
343\end{array}$ & $\begin{array}{l}5 \text { c } 4 \\
2 . \ldots \\
7 \text { c } 4 \\
5 \text { b } 3 \\
3 \text { b... }\end{array}$ & $\begin{array}{r}4494.568 \\
4517.529 \\
28.619 \\
31.152 \\
47.851\end{array}$ & $\begin{array}{r}25 \\
4 \\
15 \\
24 \\
16\end{array}$ & $\begin{array}{l}\mathbf{A} \\
\mathbf{B} \\
\mathbf{A} \\
\mathbf{A} \\
\mathbf{A}\end{array}$ & 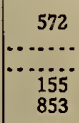 & $\begin{array}{l}571 \\
532 \\
622 \\
155 \\
854\end{array}$ \\
\hline & $\begin{array}{r}3513.821 \\
27.796 \\
56.882 \\
58.517 \\
3575.374\end{array}$ & $\begin{array}{r}11 \\
6 \\
13 \\
3 \\
10\end{array}$ & $\begin{array}{l}\text { A } \\
\text { B } \\
\text { A } \\
\text { C } \\
\text { A }\end{array}$ & $\begin{array}{c}821 \\
881 \\
38\end{array}$ & $\begin{array}{l}821 \\
881 \\
519\end{array}$ & $\begin{array}{l}2 \ldots . . \\
4 \ldots \\
4 \mathrm{~d} . . \\
4 \mathrm{~b} .\end{array}$ & $\begin{array}{r}74.725 \\
4592.655 \\
4602.945 \\
25.054 \\
47.437\end{array}$ & $\begin{array}{r}3 \\
21 \\
26 \\
14 \\
.22\end{array}$ & $\begin{array}{l}\mathbf{C} \\
\mathbf{A} \\
\mathbf{A} \\
\mathbf{A} \\
\mathbf{A}\end{array}$ & \begin{tabular}{c}
658 \\
947 \\
\hdashline$\ldots$ \\
439
\end{tabular} & $\begin{array}{r}657 \\
946 \\
\hdashline \quad 39\end{array}$ \\
\hline & $\begin{array}{r}3606.683 \\
23.188 \\
40.393 \\
76.315 \\
77.631\end{array}$ & $\begin{array}{l}24 \\
20 \\
28 \\
20 \\
20\end{array}$ & $\begin{array}{l}\mathbf{A} \\
\mathbf{A} \\
\mathbf{A} \\
\mathbf{A} \\
\mathbf{A}\end{array}$ & $\begin{array}{c}682 \\
3 \ldots 2 \\
392 \\
629\end{array}$ & $\begin{array}{l}682 \\
188 \\
392 \\
313 \\
629\end{array}$ & $\begin{array}{llll}5 & c & 4 \\
4 & c & 4 \\
5 & c & 5 \\
3 & b . \\
3 & a .\end{array}$ & $\begin{array}{r}78.853 \\
4691.414 \\
4707.282 \\
10.287 \\
33.596\end{array}$ & $\begin{array}{l}17 \\
18 \\
19 \\
17 \\
12\end{array}$ & $\begin{array}{l}\mathbf{A} \\
\mathbf{A} \\
\mathbf{A} \\
\mathbf{A} \\
\mathbf{A}\end{array}$ & $\begin{array}{c}417 \\
288 \\
\ldots . .\end{array}$ & $\begin{array}{l}290 \\
288 \\
598\end{array}$ \\
\hline $\begin{array}{l}6 \ldots . . \\
5 \ldots \\
5 \ldots\end{array}$ & $\begin{array}{r}3695.055 \\
3704.464 \\
24.381 \\
53.615 \\
3785.955\end{array}$ & $\begin{array}{r}18 \\
3 \\
30 \\
31 \\
9\end{array}$ & $\begin{array}{l}\mathbf{A} \\
\mathbf{C} \\
\mathbf{A} \\
\mathbf{A} \\
\mathbf{B}\end{array}$ & $\begin{array}{l}380 \\
615\end{array}$ & $\begin{array}{l}054 \\
464 \\
380 \\
615 \\
950\end{array}$ & 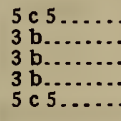 & $\begin{array}{r}36.782 \\
41.533 \\
72.818 \\
4789.654 \\
4859.748\end{array}$ & $\begin{array}{r}24 \\
8 \\
8 \\
18 \\
23\end{array}$ & $\begin{array}{l}\mathbf{A} \\
\mathbf{A} \\
\mathbf{B} \\
\mathbf{A} \\
\mathbf{A}\end{array}$ & \begin{tabular}{c}
786 \\
$\cdots \ldots .$. \\
\hdashline 657 \\
758
\end{tabular} & 790 \\
\hline$\ldots$ & $\begin{array}{r}3805.346 \\
43.261 \\
65.526 \\
73.764 \\
3891.932\end{array}$ & $\begin{array}{r}24 \\
22 \\
8 \\
16 \\
8\end{array}$ & $\begin{array}{l}\mathbf{A} \\
\mathbf{A} \\
\mathbf{B} \\
\mathbf{A} \\
\mathbf{A}\end{array}$ & $\begin{array}{l}346 \\
261 \\
527\end{array}$ & $\begin{array}{l}346 \\
260 \\
527 \\
764\end{array}$ & $\begin{array}{l}5 \text { c } 5 \\
5 \text { c5 } \\
8 \text { c } 5 \\
3 \text { a. } \\
3 a^{2} .\end{array}$ & $\begin{array}{r}4878.219 \\
4903.317 \\
19.001 \\
24.775 \\
39.692\end{array}$ & $\begin{array}{l}22 \\
21 \\
25 \\
11 \\
13\end{array}$ & $\begin{array}{l}\mathbf{A} \\
\mathbf{A} \\
\mathbf{A} \\
\mathbf{A} \\
\mathbf{A}\end{array}$ & $\begin{array}{l}225 \\
325 \\
007\end{array}$ & $\begin{array}{l}776 \\
691\end{array}$ \\
\hline a & $\begin{array}{r}3906.483 \\
07.938 \\
35.816 \\
49.958 \\
77.744\end{array}$ & $\begin{array}{l}10 \\
18 \\
22 \\
21 \\
24\end{array}$ & $\begin{array}{l}\mathbf{B} \\
\mathbf{A} \\
\mathbf{A} \\
\mathbf{A} \\
\mathbf{A}\end{array}$ & $\begin{array}{c}482 \\
937 \\
818 \\
746 \\
746\end{array}$ & $\begin{array}{r}483 \\
937 \\
817 \\
\hdashline 76\end{array}$ & $\begin{array}{l}5 \mathrm{cc} 5 \\
3 \mathrm{a}- \\
5 \mathrm{c} . \\
4 \mathrm{a} . \\
4 \mathrm{a} .\end{array}$ & $\begin{array}{r}66.097 \\
4994.132 \\
5001.872 \\
12.072 \\
41.758\end{array}$ & $\begin{array}{l}15 \\
17 \\
21 \\
23 \\
19\end{array}$ & $\begin{array}{l}\mathbf{A} \\
\mathbf{A} \\
\mathbf{A} \\
\mathbf{A} \\
\mathbf{A}\end{array}$ & \begin{tabular}{c}
104 \\
\hdashline 881 \\
073
\end{tabular} & 760 \\
\hline & $\begin{array}{r}3997.397 \\
4009.716 \\
21.870 \\
74.789 \\
76.636\end{array}$ & $\begin{array}{r}3 \\
20 \\
24 \\
21 \\
12\end{array}$ & $\begin{array}{l}\mathbf{C} \\
\mathbf{A} \\
\mathbf{A} \\
\mathbf{A} \\
\mathbf{A}\end{array}$ & $\mid$\begin{tabular}{c}
872 \\
\hdashline 642
\end{tabular} & $\begin{array}{l}397 \\
718 \\
872 \\
792 \\
638\end{array}$ & $\begin{array}{l}5 \mathrm{a} . \\
4 \mathrm{c} . \\
4 \mathrm{a} . \\
4 \mathrm{a} . \\
4 . \\
4 . .\end{array}$ & $\begin{array}{r}49.825 \\
68.774 \\
5083.343 \\
5110.414 \\
23.722\end{array}$ & $\begin{array}{l}20 \\
12 \\
18 \\
19 \\
16\end{array}$ & $\begin{array}{l}\mathbf{A} \\
\mathbf{A} \\
\mathbf{A} \\
\mathbf{A} \\
\mathbf{A}\end{array}$ & $\begin{array}{l}827 \\
334 \\
415\end{array}$ & $\begin{array}{r}827 \\
33 \% \\
415\end{array}$ \\
\hline & $\begin{array}{r}4095.974 \\
4107.492 \\
18.549 \\
34.680 \\
47.673\end{array}$ & $\begin{array}{l}19 \\
26 \\
23 \\
21 \\
24\end{array}$ & $\begin{array}{l}\mathbf{A} \\
\mathbf{A} \\
\mathbf{A} \\
\mathbf{A} \\
\mathbf{A}\end{array}$ & $\begin{array}{l}552 \\
685 \\
676\end{array}$ & $\begin{array}{l}977 \\
495 \\
552 \\
684 \\
675\end{array}$ & & & $\begin{array}{l}24 \\
20 \\
22\end{array}$ & $\begin{array}{l}\mathbf{A} \\
\mathbf{A} \\
\mathbf{A} \\
\mathbf{A} \\
\mathbf{A}\end{array}$ & 392 & $\begin{array}{r}845 \\
493 \\
\hdashline 360\end{array}$ \\
\hline 3. & $\begin{array}{r}56.802 \\
75.639 \\
84.894 \\
4191.436 \\
4203.986\end{array}$ & $\begin{array}{l}25 \\
19 \\
26 \\
20 \\
23\end{array}$ & $\begin{array}{l}\mathbf{A} \\
\mathbf{A} \\
\mathbf{A} \\
\mathbf{A} \\
\mathbf{A}\end{array}$ & 443 & $\begin{array}{l}805 \\
642 \\
897 \\
444 \\
988\end{array}$ & 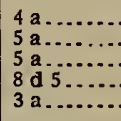 & $\begin{array}{r}5198.715 \\
5202.339 \\
16.277 \\
32.948 \\
42.496\end{array}$ & $\begin{array}{r}23 \\
9\end{array}$ & $\begin{array}{l}\mathbf{A} \\
\mathbf{A} \\
\mathbf{A} \\
\mathbf{A} \\
\mathbf{B}\end{array}$ & $\dddot{\ldots . . .}$ & $\begin{array}{l}280 \\
956 \\
496\end{array}$ \\
\hline 5 b. & $\begin{array}{l}19.364 \\
33.609 \\
45.260 \\
67.831 \\
82.406\end{array}$ & $\begin{array}{l}23 \\
20 \\
19 \\
13 \\
23\end{array}$ & $\begin{array}{l}\mathbf{A} \\
\mathbf{A} \\
\mathbf{A} \\
\mathbf{A} \\
\mathbf{A}\end{array}$ & 408 & $\begin{array}{l}367 \\
614 \\
261 \\
832 \\
408\end{array}$ & $\begin{array}{lll}3 & \ldots & \ldots \\
8 & \mathrm{~d} & 5 \\
8 & \text { a } & 4 . \\
7 & \text { d... } \\
5 & \text { d... }\end{array}$ & $\begin{array}{r}50.650 \\
66.564 \\
70.361 \\
5283.629 \\
5302.308\end{array}$ & $\begin{array}{l}12 \\
26\end{array}$ & $\begin{array}{l}\mathbf{A} \\
\mathbf{A} \\
\mathbf{A} \\
\mathbf{A} \\
\mathbf{A}\end{array}$ & $\begin{array}{l}569 \\
315\end{array}$ & $\begin{array}{r}652 \\
571 \\
360 \\
33 \\
315\end{array}$ \\
\hline 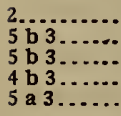 & $\begin{array}{r}4298.040 \\
4315.087 \\
37.049 \\
52.738 \\
75.932\end{array}$ & $\begin{array}{r}3 \\
20 \\
21 \\
23 \\
22\end{array}$ & $\begin{array}{l}\mathbf{A} \\
\mathbf{A} \\
\mathbf{A} \\
\mathbf{A} \\
\mathbf{A}\end{array}$ & $\begin{array}{r}089 \\
089 \\
741 \\
934\end{array}$ & $\begin{array}{l}043 \\
090 \\
052 \\
740 \\
934\end{array}$ & 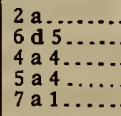 & $\begin{array}{l}07.364 \\
24.187 \\
28.532 \\
41.026 \\
71.493\end{array}$ & $\begin{array}{r}12 \\
23 \\
9 \\
24 \\
26\end{array}$ & $\begin{array}{l}\mathbf{A} \\
\mathbf{A} \\
\mathbf{C} \\
\mathbf{A} \\
\mathbf{A}\end{array}$ & 495 & $\begin{array}{l}196 \\
537 \\
028 \\
495\end{array}$ \\
\hline $\begin{array}{l}3 \mathrm{~b} . \\
4 \mathrm{c} 4 \\
5 \mathrm{a} \\
5\end{array}$ & $\begin{array}{r}4390.954 \\
4408.419 \\
27.312 \\
47.722 \\
66.555\end{array}$ & $\begin{array}{l}14 \\
16 \\
24 \\
20 \\
26\end{array}$ & $\begin{array}{l}\mathbf{A} \\
\mathbf{A} \\
\mathbf{A} \\
\mathbf{A} \\
\mathbf{A}\end{array}$ & $\left|\begin{array}{c}314 \\
556\end{array}\right|$ & $\begin{array}{l}956 \\
421 \\
314 \\
724 \\
556\end{array}$ & $\begin{array}{l}6 \mathrm{a} \\
6 \mathrm{a} \\
6 \mathrm{a} \\
6 \mathrm{a} \\
3 \mathrm{~d} .\end{array}$ & $\begin{array}{r}5397.131 \\
5405.778 \\
34.527 \\
55.613 \\
73.908\end{array}$ & $\begin{array}{r}19 \\
26 \\
28 \\
22 \\
6\end{array}$ & $\begin{array}{l}\mathbf{A} \\
\mathbf{A} \\
\mathbf{A} \\
\mathbf{A} \\
\mathbf{B}\end{array}$ & $\begin{array}{l}780 \\
527 \\
614\end{array}$ & $\begin{array}{l}134 \\
780 \\
528 \\
615\end{array}$ \\
\hline
\end{tabular}


TABLE 2.--Standard Wave Lengths in the Iron Arc Spectrum-Continued.

\begin{tabular}{|c|c|c|c|c|c|c|c|c|c|c|c|}
\hline $\begin{array}{l}\text { Intensity, } \\
\text { group, and } \\
\text { class. }\end{array}$ & $\lambda$ B. S. & $\begin{array}{l}\text { Num- } \\
\text { ber of } \\
\text { obser- } \\
\text { va- } \\
\text { tlons. }\end{array}$ & $\begin{array}{l}\text { Prob- } \\
\text { able } \\
\text { error. }\end{array}$ & \begin{tabular}{|} 
Sec- \\
ond- \\
ary \\
stand- \\
ards.
\end{tabular} & $\begin{array}{c}\text { Inter- } \\
\text { po- } \\
\text { lated. }\end{array}$ & $\begin{array}{l}\text { Intensity, } \\
\text { group, } \\
\text { and } \\
\text { class. }\end{array}$ & $\lambda$ B. $S$. & $\begin{array}{c}\text { Num- } \\
\text { ber of } \\
\text { obser- } \\
\text { va- } \\
\text { tlous. }\end{array}$ & $\begin{array}{l}\text { Prob- } \\
\text { able } \\
\text { error. }\end{array}$ & \begin{tabular}{|c|} 
Sec- \\
ond- \\
ary \\
stand- \\
ards.
\end{tabular} & $\begin{array}{c}\text { Inter- } \\
\text { po- } \\
\text { lated. }\end{array}$ \\
\hline $\begin{array}{l}4 \text { a } 3 \ldots \\
4 \text { a } 3 . . \\
5 \text { d } 5 . . \\
6 \text { d } 5 . . \\
6 \text { d } 5 . .\end{array}$ & $\begin{array}{r}5497.520 \\
5506.783 \\
69.627 \\
5586.764 \\
5615.653\end{array}$ & $\begin{array}{l}22 \\
23 \\
21 \\
24 \\
23\end{array}$ & $\begin{array}{l}\text { A } \\
\text { A } \\
\text { A } \\
\text { A }\end{array}$ & $\begin{array}{l}522 \\
784 \\
633 \\
772 \\
661\end{array}$ & $\begin{array}{l}522 \\
784\end{array}$ & $\begin{array}{llll}3 & \text { b } & 4: \\
5 & \text { b } & 4: \\
4 & \text { b } & 4: \\
3 & \text { b } & 4 .\end{array}$ & \begin{tabular}{|r|}
6191.564 \\
6219.287 \\
30.730 \\
52.562 \\
65.140
\end{tabular} & $\begin{array}{l}22 \\
11 \\
23 \\
15 \\
14\end{array}$ & $\begin{array}{l}\mathbf{A} \\
\mathbf{A} \\
\mathbf{A} \\
\mathbf{A} \\
\mathbf{B}\end{array}$ & \begin{tabular}{c}
568 \\
7334 \\
\hdashline 140 \\
\hdashline 145
\end{tabular} & $\begin{array}{l}568 \\
290 \\
734 \\
567 \\
145\end{array}$ \\
\hline $\begin{array}{l}3 \mathrm{~d} \ldots \\
3 \\
3 \mathrm{~d}\end{array}$ & $\begin{array}{r}24.551 \\
58.827 \\
5662.526 \\
5701.554 \\
09.388\end{array}$ & $\begin{array}{r}15 \\
20 \\
8 \\
10 \\
16\end{array}$ & $\begin{array}{l}\mathbf{B} \\
\mathbf{A} \\
\mathbf{B} \\
\mathbf{A} \\
\mathbf{A}\end{array}$ & $\ddot{830}$ & & $\begin{array}{lll}3 & \mathrm{~b} & 4 . \\
5 & \mathrm{~d} & 5 . \\
4 & \mathrm{~b} & 4 . \\
4 & \mathrm{~b} & 4 \\
5 & \mathrm{~b} & 4 .\end{array}$ & \begin{tabular}{|r}
6297.800 \\
6301.514 \\
18.024 \\
35.338 \\
6393.607
\end{tabular} & $\begin{array}{r}6 \\
18 \\
16 \\
18 \\
22\end{array}$ & $\begin{array}{l}\text { A } \\
\text { A } \\
\text { A } \\
\text { A }\end{array}$ & $\begin{array}{l}-0028 \\
341 \\
612\end{array}$ & $\begin{array}{l}803 \\
003 \\
028 \\
342 \\
612\end{array}$ \\
\hline $\begin{array}{l}4 \mathrm{e} . \\
6 \mathrm{e} . \\
4 \ldots\end{array}$ & $\begin{array}{r}53.131 \\
5563.002 \\
5862.354 \\
5914.172 \\
5934.668\end{array}$ & $\begin{array}{r}6 \\
15 \\
5 \\
3 \\
6\end{array}$ & $\begin{array}{l}\mathbf{B} \\
\mathbf{B} \\
\mathbf{B} \\
\mathbf{A} \\
\mathbf{C}\end{array}$ & 013 & & $\begin{array}{l}5 \mathrm{~d} \\
5 \mathrm{~d} \\
4 \mathrm{~b} \\
5 \mathrm{~b} \\
5 \mathrm{~b}\end{array}$ & $\begin{array}{r}6400.014 \\
11.662 \\
21.355 \\
30.853 \\
6494.987\end{array}$ & $\begin{array}{r}4 \\
4 \\
17 \\
22 \\
24\end{array}$ & $\begin{array}{l}\mathrm{B} \\
\mathrm{C} \\
\mathrm{A} \\
\mathrm{A} \\
\mathrm{A}\end{array}$ & $\begin{array}{r}859 \\
993 \\
993\end{array}$ & $\begin{array}{l}36 . \\
362 \\
859 \\
993\end{array}$ \\
\hline 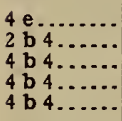 & $\begin{array}{r}6024.066 \\
27.058 \\
6065.489 \\
6136.623 \\
37.697\end{array}$ & $\begin{array}{r}14 \\
6 \\
20 \\
6 \\
21\end{array}$ & $\begin{array}{l}\mathbf{A} \\
\mathbf{A} \\
\mathbf{A} \\
\mathbf{C} \\
\mathbf{A}\end{array}$ & $\begin{array}{r}059 \\
492 \\
701 \\
701\end{array}$ & $\begin{array}{l}059 \\
492 \\
624 \\
702\end{array}$ & $\begin{array}{lll}5 & \mathrm{~b} & 4 . \\
5 & \mathrm{~b} & 4 . \\
4 & \mathrm{~b} & 4 . \\
5 & \mathrm{~b} & 4 .\end{array}$ & \begin{tabular}{|l}
6546.247 \\
6592.920 \\
6663.447 \\
6677.994
\end{tabular} & $\begin{array}{r}18 \\
16 \\
6 \\
17\end{array}$ & $\begin{array}{l}\mathrm{A} \\
\mathrm{A} \\
\mathrm{B} \\
\mathrm{B}\end{array}$ & \begin{tabular}{r}
252 \\
928 \\
\hdashline .004 \\
8.004
\end{tabular} & $\begin{array}{r}252 \\
927 \\
455 \\
8.001\end{array}$ \\
\hline
\end{tabular}

\section{DISCUSSION.}

Table 2 shows, first of all, that the values for $c$ and $d$ lines as derived from the long arc are distinctly smaller than the adopted secondaries, thus confirming in a qualitative way the results of St. John and Babcock, who found that the lines of groups $\mathrm{c}$ and $\mathrm{d}$ were displaced with respect to the lines of groups a and b. For 23 lines belonging to groups $c$ and $d$ the secondary standards minus our new values averages $+0.0072 \mathrm{~A}$.

It is also evident that there is a systematic difference for the remaining lines, 44 of which have been recognized as belonging to groups $a$ and $b$. The difference between the international values and our redeterminations averages $+0.0029 \mathrm{~A}$ for these 44 lines. We have searched diligently for an explanation of this divergence, but are unable to account for it in an entirely satisfactory manner. It was suspected that at least a part of the difference might be ascribed to a change in wave length of $a$ and $b$ lines when these are derived from the long arc instead of from the short one, which served as a source for the internationally adopted measurements. An independent investigation on standards among the longer waves of iron was made recently with a 6-mm 6-ampere arc. ${ }^{18}$ Omitting poor determinations, 34 lines with group designations are common to these two sets of measurements; these are given in Table 3 for purposes of comparison. Ten lines of group $d$ average 
$0.0047 \mathrm{~A}$ longer in the shorter arc, but the average value for 22 lines of groups $\mathrm{a}$ and $\mathrm{b}$ is only $0.0004 \mathrm{~A}$ greater in the shorter arc. In other words, the new measurements with the short arc deviate from the so-called stable international standards by nearly the same amounts as the redeterminations from the new arc, indicating that the modifications in the arc do not change these values more than a few ten-thousandths of an Angstrom.

TABLE 3.-New Values from Long and Short Arcs Compared with Secondaries.

\begin{tabular}{|c|c|c|c|c|c|c|c|}
\hline $\begin{array}{l}\text { Intensity, group, } \\
\text { and class. }\end{array}$ & $\begin{array}{c}12-\mathrm{mm} \\
\text { 5-ampere } \\
\text { arc. }\end{array}$ & $\begin{array}{c}\text { 6-mm } \\
\text { 6-ampere } \\
\text { arc. }\end{array}$ & $\begin{array}{l}\text { Second- } \\
\text { aries. }\end{array}$ & $\begin{array}{l}\text { Intensity, group, } \\
\text { and class. }\end{array}$ & $\begin{array}{l}12 \text {-mm } \\
\text { 5-ampere } \\
\text { arc. }\end{array}$ & $\begin{array}{l}\text { 6-mm } \\
\text { 6-ampere } \\
\text { arc. }\end{array}$ & $\begin{array}{l}\text { Second- } \\
\text { aries. }\end{array}$ \\
\hline 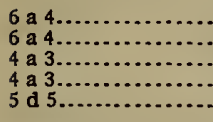 & $\begin{array}{r}5434.527 \\
55.613 \\
5497.520 \\
5506.783 \\
67.627\end{array}$ & $\begin{array}{l}525 \\
614 \\
520 \\
782 \\
631\end{array}$ & $\begin{array}{l}527 \\
614 \\
522 \\
784 \\
633\end{array}$ & 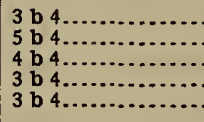 & $\begin{array}{r}6219.287 \\
30.730 \\
52.562 \\
65.140 \\
6297.800\end{array}$ & $\begin{array}{l}286 \\
730 \\
564 \\
140 \\
800\end{array}$ & י34 \\
\hline 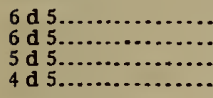 & \begin{tabular}{|r|}
5586.764 \\
5615.653 \\
24.551 \\
58.827
\end{tabular} & $\begin{array}{l}770 \\
658 \\
555 \\
834\end{array}$ & $\begin{array}{r}772 \\
661 \\
-336\end{array}$ & $\begin{array}{lll}5 & b & 5 \ldots \\
4 & b & 4 \\
4 & b & 4 \ldots \\
5 & b & \ldots \ldots\end{array}$ & $\begin{array}{r}6301.514 \\
\checkmark 18,024 \\
35.338 \\
6393.607\end{array}$ & $\begin{array}{l}515 \\
025 \\
338 \\
608\end{array}$ & $\begin{array}{l}028 \\
341 \\
612\end{array}$ \\
\hline 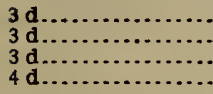 & $\begin{array}{r}5662.526 \\
5709.388 \\
53.131 \\
5763.002\end{array}$ & $\begin{array}{l}529 \\
392 \\
138 \\
009\end{array}$ & $\begin{array}{l}396 \\
013\end{array}$ & 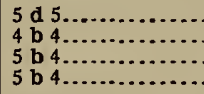 & $\begin{array}{r}6400.014 \\
21.355 \\
30.853 \\
6494.987\end{array}$ & $\begin{array}{l}018 \\
356 \\
853 \\
988\end{array}$ & $\begin{array}{l}859 \\
993\end{array}$ \\
\hline $\begin{array}{l}4 \\
4\end{array}$ & $\begin{array}{r}6024.066 \\
6065.489 \\
37.697 \\
6191.564\end{array}$ & $\begin{array}{l}060 \\
489 \\
699 \\
565\end{array}$ & $\begin{array}{l}492 \\
701 \\
568\end{array}$ & 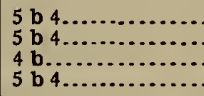 & $\begin{array}{l}6546.247 \\
6592.920 \\
6663.447 \\
6677.994\end{array}$ & $\begin{array}{l}247 \\
922 \\
447 \\
994\end{array}$ & $\begin{array}{r}252 \\
928 \\
\ldots .004\end{array}$ \\
\hline
\end{tabular}

Considering the circumstances under which the original observations were made, we have been forced to the conclusion that the adopted system of international secondary and tertiary standards may be slightly in error. As stated before, the wave-length comparisons upon which the international standards are based were made before the effects of certain variations in operating conditions of the sources were appreciated or quantitatively determined. The so-called pole effect in the iron arc is an example of the resulting uncertainty in a wave length when the source is not accurately described. Similar uncertainty may exist for the cadmium standard when the original source which defined the unit of wave length (International Angstrom unit) is not adhered to. In all of our work on secondary standards we have used, as the primary standard, the low vapor-pressure cadmium tube, whose red radiation was measured relative to the meter, and our experience with this source indicates that the wave length of the red line is constant and reproducible well within the limiting precision attainable in wave-length comparisons. ${ }^{19}$ 
It is to be regretted that other laboratories have not made more use of this source, and it is, perhaps, a serious matter that none of the measurements on which the international system was based were made directly from the primary standard as defined. Fabry and Buisson ${ }^{20}$ in measuring I 5 iron lines (2374 to $6495 \mathrm{~A}$ ) referred these to an auxiliary standard $(5460.74 \mathrm{I}$ A) from the mercury spectrum as emitted by a Cooper-Hewitt lamp. This line is known to have a very complex fine structure and its effective wave length in interferometers is, therefore, highly irregular. ${ }^{21}$ Eversheim ${ }^{22}$ employed the Heraeus arc lamp, which contained a cadmium amalgam and was operated with 4.5 amperes on a 220-volt circuit. Furthermore, the complex blue line (5085.822 A) was often used instead of the red line $(6438.4696 \mathrm{~A})$. A similar cadmium arc and procedure was employed by Pfund. ${ }^{23}$

Discrepancies and systematic differences, exceeding the probable errors, exist among these first determinations. ${ }^{24}$ For example, the standard $6678.004 \mathrm{~A}$ is based upon the observations 8.000, 8.004, and $8.008 \mathrm{~A}$, while our value from either the short or the long arc is $6677.994 \mathrm{~A}$.

It may, therefore, be questioned if the adopted system of secondary standards is in a sufficiently satisfactory condition, since it is not based on the strictly defined primary standard, and the values were obtained before detailed specifications for the iron arc existed. The accuracy of both absolute and relative values might be increased by remeasurement with the long arc which gives somewhat sharper lines. In our opinion, it is highly desirable to have a system of international standards of wave length determined as accurately as possible, and strictly according to the logical definitions of such a system.

Washington, August 20, 1923.

${ }^{20}$ Astroph. Jour., 28, p. 169; 1908.

${ }^{21}$. Perard, Comptes Rendus., 176, p. ro6o; 1923.

${ }^{22}$ Ann. der Phys., 30, p. 815; r9og.

${ }^{23}$ Astroph. J., 28, p. 197; 1908.

${ }^{24}$ Phys. Rev., 31, p. 602; 19 ro. 